\title{
Changes in the concentration of sugars in developing ovules
}

\author{
Zmiany $w$ stężeniu cukrów $w$ rozwijających się zalażkach
}

\author{
M. RYCZKOWSKI
}

\section{INTRODUCTION}

In his previous papers $(1960 \mathrm{a}, \mathrm{c})$ the author presented the results of his studies on the osmotic value of the central vacuolar sap in developing ovules. It has been established that this value increases with the age of the ovules in all examined species, till it attains a determined level and subsequently drops and remains on a more or less constant level. In order to explain this phenomenon, a hypothesis was advanced (in the paper 1960a) that the fluctuations of the osmotic value of the central vacuolar sap during the development of the ovules are the result of two processes; the first consists in the transfer of nutrative substances (amino acids, sugars) to the ovule from the vegetative organs (Prokofiev and Sobolyev 1957, Zhdanova, Lebedyev, $\mathrm{C} \mathrm{h}$ vi $\mathrm{zh} \mathrm{1960),} \mathrm{the} \mathrm{second} \mathrm{is} \mathrm{the} \mathrm{synthesis} \mathrm{of} \mathrm{storage} \mathrm{substances} \mathrm{of} \mathrm{low}$ osmotic activity (protein, polisaccharides) in the developing endosperm (Koblet 1940, Evans 1941, Kolobkova 1958, Grzesiuk and Rejowski 1960). Further investigations on the changes of the amount of carbohydrates and nitrogen compounds occuring in the central vacuolar sap during the growth and development are necessary to corroborate or disprove this hypothesis.

It should be noticed that the above mentioned two groups of compounds were and will be essential for cultures in vitro both of the embryos and of the nuclear endosperm ( $\mathrm{S}$ a n ders, B u r k holde r 1948, C utter jr. and Wils on 1954, Ba jer 1955, 1957, Stra us 1960).

This study has been carried out in order to:

1) determine the concentration of soluble sugars in the sap of the central vacuole during the growth and development of the ovules; 
2) discover any dependence between the concentration of sugars in the sap, the water content and the synthesis of storage compounds in developing ovules.

\section{MATERIAL AND METHOD}

The ovules of Clivia sp., Haemanthus Katharinae and Haemanthus albiflos provided the material used in these studies. The criterion adopted for the estimation of the developmental stage of the ovules and the method elaborated for the measurements of their size were described in the previous papers (1960a, c).

The following procedure was adopted for the extraction of the vacuolar sap. An isolated ovule was punctured with a glass needle and pressed delicatly with two fingers in order to force the sap out. The drops of clear sap were collected in a previously prepared sterile pipette graduated to $0,001 \mathrm{ml}$.

The micro-method of Somogyi (1945) modified by Willis and Y e m m (1955) was applied for estimations of the sugar concentration in the sap of the central vacuole. The amount of applied reagents, the preparation and storage procedures were the same as those recommended by the above mentioned investigators. The author finds it advisable to notice that the copper reagent and the sugar samples were warmed in a water bath $\left(100^{\circ} \mathrm{C}\right)$ for 21 minutes and 15 minutes respectively. Both the copper reagent and the sugar samples were cooled for 3 minutes in tap water (not running) before further use. The time of warming and cooling the samples was observed with accuracy to 2 seconds. A blank test was made simultanously with the main test both

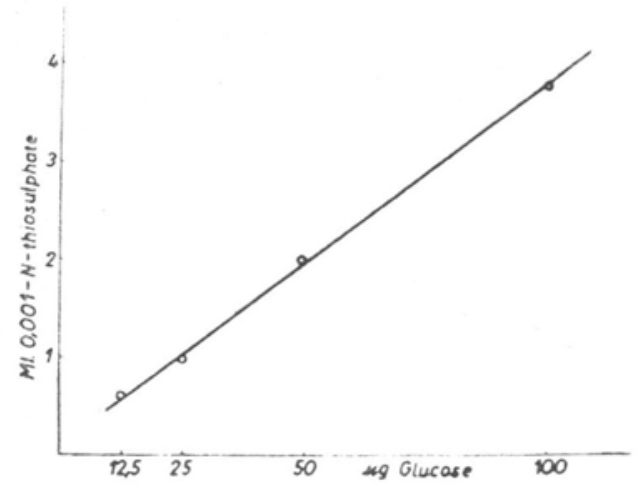

Fig. 1. Relation between the concentrations of the standard dilution of glucose in $\mu \mathrm{g} / \mathrm{ml}$ and the amount of $0,001-\mathrm{N}-\mathrm{Na}_{2} \mathrm{~S}_{2} \mathrm{O}_{3}$ in $\mathrm{ml}$ necessary for titration

during calibration and estimation of sugars in the sap of the central vacuole. Calibration was carried out by means of two standard solutions of sugars: glucose and saccharose. The results of calibration by means of glucose solution are shown in Fig. 1. They indicate that the relation 
between the sugar content in the sample and the amount of $0.001-\mathrm{N}-\mathrm{Na}_{2} \mathrm{~S}_{2} \mathrm{O}_{3}$ utilized for its titration is exactly linear in the examined range of glucose concentration (12.5-100 $\mu \mathrm{g})$. An analogous relation was obtained for the standard solution of saccharose, though, the amounts of $0.001-\mathrm{N}-\mathrm{Na}_{2} \mathrm{~S}_{2} \mathrm{O}_{3}$ utilized for titration of identic doses of saccharose and glucose, were somewhat smaller. This is in conformity with the results obtained by Willis and Yem (1955). In the range $12.5-100 \mu \mathrm{g}$ with the standard solution of glucose and saccharose the error of estimation did not exceed 1 or $2 \mu \mathrm{g}$ respectively. For estimations, the solution which contained the sugars of the central vacuolar sap was prepared according to the $\mathrm{Yemm}$ and $\mathrm{W}$ illi is (1954) prescription. Before analysis this solution (containing sugars, amino-acids, protein and other compounds and cleared with aluminium hydroxyd cream) was centrifugated for 20 minutes at 5000 r.p.m. The supernatant solution, the volume of which was $0.5-1 \mathrm{ml}$ (in dependence on the stage of development of the ovules) provided the material for the estimation of sugars; they were determined in the following order: 1) reducing sugars, 2) all sugars present in the solution (after hydrolysis). The hydrolysis of non reducing sugars was performed by applying $0.2-\mathrm{N}-\mathrm{H}_{2} \mathrm{SO}_{4}$ for 10 minutes in a water bath at $100^{\circ} \mathrm{C}$. The non reducing sugars constituted the difference between the total amount of sugars and reducing sugars.

The amounts of reducing sugars were calculated from the standard curve obtained for glucose. whereas total sugars were determined from the standard curve obtained for saccharose. The results of estimation of sugars are shown in Fig. 2, 3 and in Table 3. They are given in $\mathrm{mg}$ for $1 \mathrm{ml}$ sap of the central vacuole.

The water content in the ovules was determined by the weighing method. Isolated ovules were dried at $105^{\circ} \mathrm{C}$ to a constant weight. The material for examination was collected between 7 and 9 a.m. Examinations were performed in Summer 1960.

\section{RESULTS}

Clivia sp. The results of determination of soluble sugars in the sap of the central vacuole in the ovules of this plant species are shown in Fig. 2 (curve I - reducing sugars, II - all soluble sugars after hydrolysis, III - non reducing sugars). The concentration of reducing sugars in the sap of 9 days old ovules is $20 \mathrm{mg} / \mathrm{ml}$ sap and increases gradually during the further growth of the ovules and in 17 days old ones it attains $28-29 \mathrm{mg} / \mathrm{ml}$ sap. Subsequently it slightly drops (24 days old ovules) and finally it attains the value $40 \mathrm{mg} / \mathrm{ml}$ sap in 43 days old ovules. In still older ones a rapid drop of reducing sugars to $12 \mathrm{mg} / \mathrm{ml}$ 
sap (50 days old ovules) was observed. In ovules $53-54$ days old the concentration of these sugars is slightly greater in ccmparison to 50 days old ones and is $20 \mathrm{mg} / \mathrm{ml}$. The total concentration of soluble sugars in the central vacuolar sap (curve II) in $9-24$ days old ovules increases

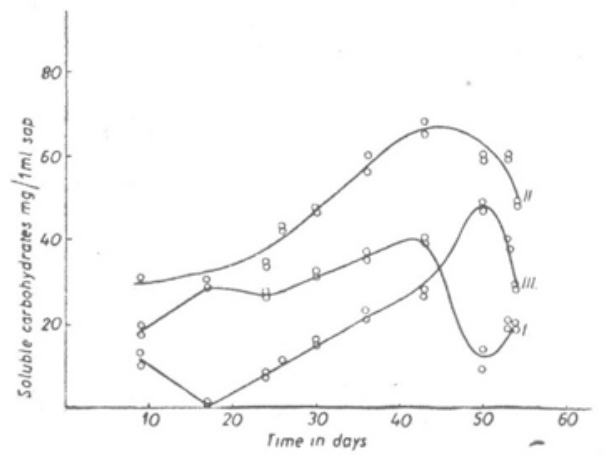

Fig. 2. Clivia sp. Changes in the concentration $(\mathrm{mg} / \mathrm{ml})$ of sugars in the sap of the central vacuole in dependence on the age of the ovules; abscissae: days from the moment the perianth dropped

(Curve $I-$ reducing sugars, $I I-$ all soluble sugars after hydrolysis, $I I I$ - non reducing sugars)

slowly from 30 till $35 \mathrm{mg} / \mathrm{ml}$ sap. The total amount of soluble sugars in the sap of ovules in the age of 24 and 43 days increases rapidly from 35 to $65 \mathrm{mg} / \mathrm{ml} \mathrm{sap.} \mathrm{In} \mathrm{older} \mathrm{ovules} \mathrm{(over} 43$ days) a decrease to $50 \mathrm{mg} / \mathrm{ml}$ of the total amount of soluble sugars in the sap of the central vacuole (54 days old ovules) is observed. The concentration of non-reducing sugars in 9 days old ovules is $11 \mathrm{mg} / \mathrm{ml} \mathrm{sap}$, in older ones (17 days old) it decreases to 0 , fig. 2 (curve III). In ovules from the 17 to the 50 th day the concentration of non reducing sugars in the sap of the central vacuole increases almost from 0 to $47 \mathrm{mg} / \mathrm{ml}$ sap. A lower concentration of non-reducing sugars in the sap $(39-30 \mathrm{mg} / \mathrm{ml})$ is characteristic of ovules 53 to 54 days old.

The percentage of water content in relation to fresh weight in $9-43$ days old ovules fluctuates between $91-93 \%$ (Tab. 1), the lowest water content (about 91\%) was found in ovules in the 9th and 43rd day. A slow decrease of water content from 91 to $88 \%$ is characteristic of older ovules ( $43-87$ days). Within 78 days (between the 9 th and 87 th day) the water content calculated for 1 ovule increase from 21.5 to $1331 \mathrm{mg}$. In this range of time one may distinguish two periods of intensive increase of water content. During the first period ( $9-17$ day) the water content increases about 5 times. During the second one ( 38 - 43 days old ovules) the water content becomes about twice as great.

During growth and development the dry weight of 1 ovule rises from $2 \mathrm{mg}$ ( 9 days old ovules) to $178 \mathrm{mg}$ ( 87 days old ovules). Similarly to the increase of water content, we can distinguish two periods of intensive rise of the dry weight of the ovules (in $17-26$ and $38-43$ days old ovules). 
Table 1

Clivia sp. - Water content of the ovules and their dry weight in dependence on their age (days after the perianth dropped)

\begin{tabular}{r|c|c|c}
\hline Days & $\begin{array}{c}\text { Water content } \\
\%\end{array}$ & $\begin{array}{c}\text { Water content } \\
\text { 1 ovule in mg }\end{array}$ & $\begin{array}{c}\text { Dry weight } \\
\text { 1 ovule in mg }\end{array}$ \\
\hline 9 & 91.5 & 21.5 & 2.0 \\
17 & 93.0 & 100.6 & 7.5 \\
21 & 92.6 & 142.2 & 11.3 \\
26 & 92.2 & 251.0 & 21.2 \\
27 & 92.6 & 224.2 & 18.0 \\
30 & 92.9 & 227.0 & 17.2 \\
34 & 93.0 & 311.4 & 24.4 \\
38 & 93.0 & 250.8 & 19.0 \\
43 & 91.1 & 446.4 & 43.8 \\
50 & 90.4 & 682.8 & 72.3 \\
56 & 90.4 & 701.0 & 74.9 \\
65 & 89.8 & 1061.6 & 121.4 \\
75 & 88.4 & 990.0 & 129.4 \\
87 & 88.2 & 1331.3 & 178.4 \\
& & &
\end{tabular}

It results frcm the ccmparison of the results presented in Table I and Fig. 2 that the concentrations of total sugars, reducing sugars and non reducing sugars increase in general concomitantly with the increase of water content calculated for 1 ovule (ovules in the age of $9-43$ days). A decrease of concentration of total and reducing sugars and a further decrease of water content calculated for 1 ovule was observed in older ovules ( $43-54$ days old). The percentage of water content in these ovules in relation to fresh weight drops concomitantly, whereas the amount of non reducing sugars increases still for a time (50 days old ovules) and subsequently drops. The highest content of water calculated for 1 ovule was observed, for an 8 days long period, in $9-17$ days old ovules in which reducing sugars were preponderant. Another maximal value of water content calculated for 1 ovule was found in $38-43$ days old ovules i.e. at the age when the concentration of total sugars and reducing sugars in the sap of the central vacuole attains its maximum. In this period reducing sugars intensively change into non-reducing compound sugars.

Two distinct stages of intensive rise of dry weight can be distinguished a) in $17-26$ days old ovules, when the concentration of total sugars in the sap of the central vacuole increases slowly and b) in $38-43$ days old ovules when the maximal value of the concentration of sugars and reducing sugars is attaired, but the concentration of non reducing sugars still increases (50 days old ovules). 
Haemanthus Katharinae. The results of sugar estimations in the sap of the central vacuole in ovules of H. Katharinae are shown in Fig. 3. These results are similar to those obtained for Clivia sp. with the difference, however, that changes in the sugar concentrations proceed at

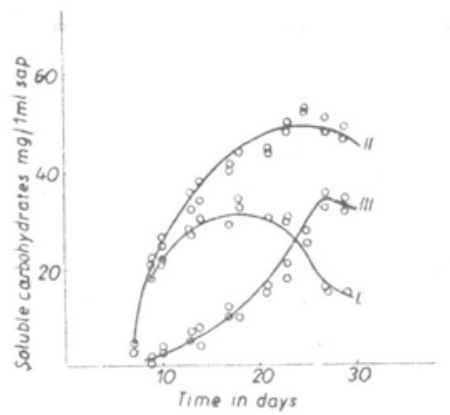

Fig. 3. Haemanthus Katharinae. Changes in the concentration of sugars in the sap of the central vacuole in dependence on the age of ovules. Abscissae: days from the moment the perianth wilted

(Curve I, II, III see FHg. 2)

a more rapid rate than in ovules of the latter species. The amounts of different sugars (reducing, total and non reducing sugars) are lower than in the case of Clivia sp.

Table 2

Haemanthus Katharinae - Water content of the ovules and their dry weight in dependence on their age (days after the perianth wilted)

\begin{tabular}{|c|c|c|c|}
\hline Days & $\begin{array}{c}\text { Water content } \\
\% \\
\text { fresh weight }\end{array}$ & $\begin{array}{l}\text { Water content } \\
1 \text { ovule in } \mathrm{mg}\end{array}$ & $\begin{array}{c}\text { Dry weight } \\
1 \text { ovule in } \mathrm{mg}\end{array}$ \\
\hline 7 & 91.9 & 13.9 & 1.2 \\
\hline 11 & 92.7 & 22.2 & 1.7 \\
\hline 12 & 89.7 & 28.5 & 3.3 \\
\hline 13 & 89.3 & 29.5 & 3.6 \\
\hline 16 & 90.9 & 35.1 & 3.5 \\
\hline 18 & 90.6 & 48.4 & 5.0 \\
\hline 18 & 90.7 & 45.0 & 4.6 \\
\hline 21 & 90.7 & 56.3 & 5.8 \\
\hline 23 & 90.2 & 75.8 & 8.2 \\
\hline 27 & 91.3 & 85.3 & 12.2 \\
\hline 28 & 90.7 & 124.6 & 12.7 \\
\hline 29 & 90.3 & 110.5 & 11.9 \\
\hline 32 & 90.4 & 142.4 & 15.1 \\
\hline 32 & 90.2 & 145.0 & 15.8 \\
\hline 33 & 90.1 & 136.8 & 15.1 \\
\hline 36 & 89.8 & 151.1 & 17.1 \\
\hline 43 & 89.3 & 214.0 & 25.6 \\
\hline 45 & 88.7 & 232.9 & 29.8 \\
\hline 48 & 87.3 & 263.8 & 38.5 \\
\hline 53 & 86.8 & 302.9 & 46.2 \\
\hline 54 & 86.6 & 290.0 & 44.9 \\
\hline
\end{tabular}


The changes in water content and dry weight of the ovules during their growth and development are presented in Table 2. The water content of younger ovules (percent of fresh weight) fluctuates about $90.5 \%$ ( $7-33$ days old ovules). A slow decrease from $90 \%$ to $86 \%$ (33 to 54 days old ovules) is characteristic of older ovules. The water content calculated for 1 ovule in the age $7-54$ days rises from 13.9 to $290 \mathrm{mg}$, whereas, the dry weight of one ovule increases from 1.24 to $44.9 \mathrm{mg}$.

Haemanthus albiflos. Neither the water content nor the dry weight in the ovules of this species were determined. The results of sugar estimations in the central vacuolar sap are assembled in Table 3 according to the size of the ovules. In ovules of the size $2.5 \times 4.4 \mathrm{~mm}$ the concentration of the reducing sugars is the highest $(30-31 \mathrm{mg} / \mathrm{ml} \mathrm{sap})$ and decreases gradually as the ovules grow older to $16-17 \mathrm{mg} / \mathrm{ml} \mathrm{sap}$ (size of ovules $5.4 \times 7.3 \mathrm{~mm}$ ). In ovules $2.5 \times 4.4 \mathrm{~mm}$ in size the concentration of total sugars in the central vacuolar sap fluctuates about $38-40 \mathrm{mg} / \mathrm{ml}$ sap and increases gradually till $64-67 \mathrm{mg} / \mathrm{ml}$ sap (ovules $4.5 \times 6.6 \mathrm{~mm}$ ) and then drops to $55-56 \mathrm{mg} / \mathrm{ml}$ sap (ovules $5.4 \times 7.3 \mathrm{~mm}$ ). Concomitantly with these changes, changes of non reducing sugars take place in the sap of the central vacuole; the amounts of these sugars gradually increase to $44-48 \mathrm{mg} / \mathrm{ml}$ sap (ovules $4.5 \times 6.6 \mathrm{~mm}$ ) and then drop to $39 \mathrm{mg} / \mathrm{ml}$ sap (ovules $5.4 \times 7.3 \mathrm{~mm}$ ).

Table 3

Haemanthus albiflos. Concentration of sugars in the sap of the central vacuole in dependence on the size of the ovules

\begin{tabular}{c|c|c|c}
\hline $\begin{array}{c}\text { Size of } \\
\text { ovule } \\
\text { in } \mathrm{mm}\end{array}$ & $\begin{array}{c}\text { Free reducing } \\
\text { sugars } \\
\mathrm{mg} / \mathrm{ml}\end{array}$ & $\begin{array}{c}\text { Total soluble } \\
\text { carbohydrates } \\
\text { (after hydrolysis) } \\
\mathrm{mg} / \mathrm{ml}\end{array}$ & $\begin{array}{c}\text { None reducing } \\
\text { sugars } \\
\mathrm{mg} / \mathrm{ml}\end{array}$ \\
\hline \multirow{3}{*}{$2.5 \times 4.4$} & 30.000 & 38.333 & 8.333 \\
& 31.389 & 40.556 & 9.167 \\
$3.3 \times 5.1$ & 23.750 & 48.000 & 24.250 \\
& 19.625 & 45.000 & 25.375 \\
$4.2 \times 6.2$ & 19.000 & 58.500 & 39.500 \\
& 19.000 & 56.500 & 37.500 \\
$4.5 \times 6.6$ & 19.250 & 67.000 & 48.750 \\
& 17.500 & 64.000 & 44.750 \\
$5.4 \times 7.3$ & 16.375 & 55.500 & 39.125 \\
& 17.000 & 56.500 & 39.500 \\
& & &
\end{tabular}

\section{DISCUSSION}

The determination of the sugar content in the sap of the central vacuole during the growth of the ovules belonging to the three examined 
species (Clivia sp., Haemanthus Katharinae and Haemanthus albiflos) yielded similar results. It is therefore reasonable to restrict the discussion to one species only e.g. Clivia sp.

Considering that the size of the central vacuole increases in ovules $9-40$ days old ( $R$ y c z k ow ski 1960c), one may see from the results shown in Table 1 that the rise of the concentration of total sugars from $30-65 \mathrm{mg} / \mathrm{ml}$ sap (Fig. 2) is connected with an inflow of water and other organic and inorganic compounds from vegetative organs of the plant to the ovule.

During the further growth and development of the ovules (from the 43rd to the 54th day of age) the total concentration of sugars decreases in spite of the rise of the water content calculated for 1 ovule. This is, however, only an apparent discrepancy, as, at the same time, a drop of percentage of water content in relation to fresh weight of the ovules was observed. This intensive increase of dry weight in ovules between the 17 th and 26 th day and $38-43$ days old ones is connected not only with the increase of sugar concentration in the sap of the central vacuole. The results refering to the concentration of sugars in the sap of the central vacuole indicate that the absolute amounts of the three groups of sugars change in the course of growth and development of the ovules and the synthesis of non reducing sugars takes place at the cost of reducing sugars and in turn, starch is formed at the cost of non reducing sugars.

The obtained results are, as a rule, in conformity with those obtained by other investigators for whole wheat and corn grains. Koblet (1940) established that the sugar content in a wheat grain attained $2.2 \mathrm{~g}$ for 1000 grains on the 13 th day following the beginning of blooming. Subsequently it gradually decreases till on the 35th day it was only $0,9-1,2 \mathrm{~g}$, whereas, the content of protein and specially of starch increases concomitantly. Evans (1941) examined the chemical composition of a developing corn grain after silking and found that the content of such sugars as sucrose and dextrose expressed on dry weight basis, amounts to $5.24 \%$ and $3.8 \%$ on the 15 th day. It decreases with age and on the 57th day it is $2.33 \%$ and $0.74 \%$. The starch content in a grain on the 15 th day is $22.8 \%$ and increases rapidly with its age and on the 36 th day it attains a constant value $71.8 \%$. There is a difference between the results presented in this parer and those obtained by Koblet (1940) and Evans (1941), but it is caused by the fact that these investigators experimented on an older material than the author (Koblet the 13th day following blocming and Evans the 15th day after silking). Thus, most probably, their first estimations of sugar content were performed at a time when the sugar content in a wheat 
and a corn grain attains its maximal value. The results of estimation of water soluble sugars in a corn grain obtained by $\mathrm{Grzesi} \mathrm{u} \mathrm{k} \mathrm{and} \mathrm{Re}$ jowski (1960), may be regarded as an argument suporting this divergence of results. They have established that the sugar content in a corn grain on the 12 th day after anthesis is $28 \%$ on dry weight basis, on the 17th day it exceeds $38 \%$ and subsequently drops with the age of the grain to $4 \%$ (the 56 th day after anthesis). The fact that $\mathrm{Ko} \mathrm{ble} \mathrm{t}$ (1940) and Evans (1941) used whole grains, whereas the author made his experiments on the central vacuolar sap, might have had a certain influence on the divergence of results.

The author prepared a supplementary graph (Fig. 4) permitting a more detailed analysis of changes of the physical and chemical properties shown by the central vacuolar sap during the growth and

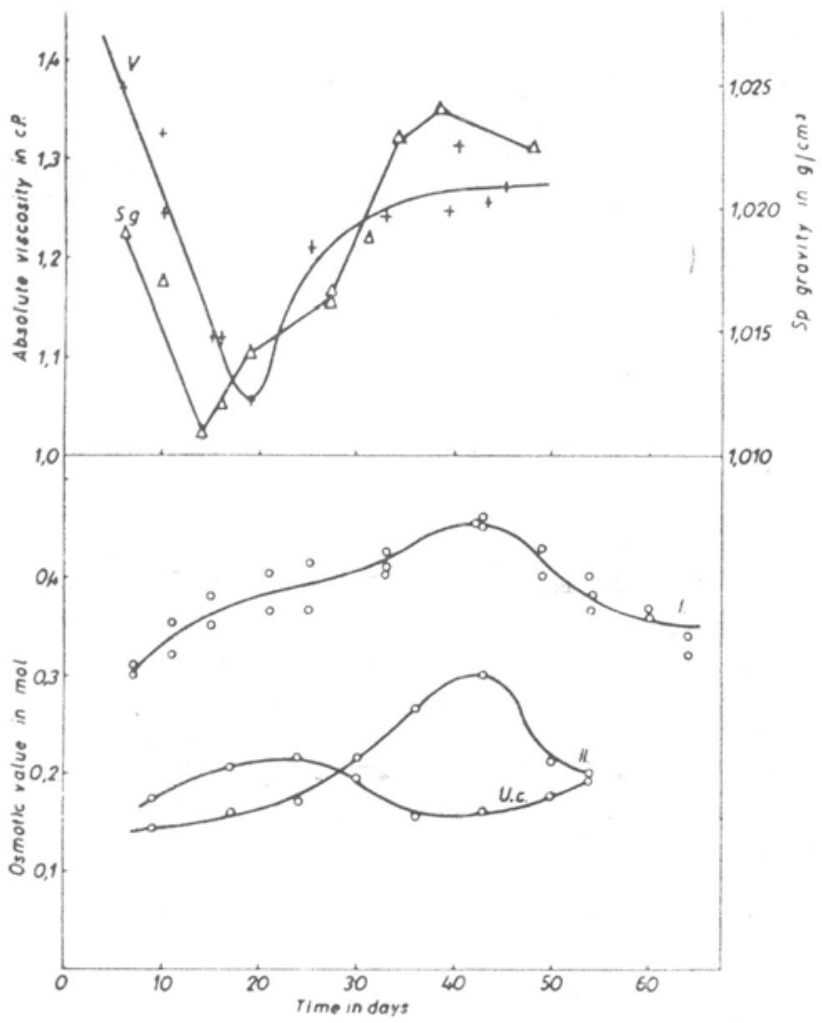

Fig. 4. Clivia sp. Abscissae: time in days. S.g. - specific gravity of the sap of the central vacuole

$\boldsymbol{v}$ - viscosity of the sap. Curve $I$ - osmotic value of the sap (see paper 1960c). Curve II osmotic value of the sap calculated from the sum of the concentrations of reducing and non= -reducing sugars in the sap of the central vacuole. U.c. - undetermined compounds in the sap of the central vacuole 1.e. differenee between curves $\boldsymbol{I}$ and $I I$ 
development of ovules of Clivia sp. In this graph are shown the curves representing the osmotic value, the viscosity, the specific gravity of the central vacuolar sap and curve II which results from expressing the content of reducing and non reducing sugars in terms of osmotic value (in moles per liter). The curve denoted on the graph U.c. (undetermined compounds) represents the difference between the osmotic value, shown in Fig. 4 as curve I (Ryczkowski 1960c, Clivia sp. curve I) and the osmotic value of the central vacuolar sap shown in Fig. 4 as curve II. An analogous curve was obtained also for the sap of the central vacuole in the ovules of $H$. Katharinae. It should be noticed that nitrogen compounds (Kolobkova 1958, Pontovich, Karimov 1960) are most probably the principal compounds shown in Fig. 4 as curve U.c. One may see from Fig. 4 that the specific gravity and the viscosity of the sap of the central vacuole in young $(4-5$ to 19 days old) ovules decrease (the causes of this phenomenon are explained in paper Ryczkowski 1960 d) and subsequently rises till more or less constant values are attained (39-48 days old ovules). The specific gravity which is the resultant of the concentrations of all substances present in the sap of the central vacuole, begins to increase at an earlier age of the ovules (14 days old ovules) than the viscosity (19 days old ovules) because the latter one is determined first of all by protein substances, which begin to accumulate in the sap at an older age. An intensive increase of dry weight was observed to occur twice (in $17-26$ and $38-41$ days old ovules). The first rise took place at the time when an increase of specific gravity, viscosity and concentration of sugars and undetermined compounds (Fig. 4) was observed in the sap of the central vacuole. The second period of an increase of dry weight coincides with the moment when the specific gravity, viscosity and concentration of sugars in the sap of the central vacuole attain their maximal values (38-45 days old ovules). At this age of ovules and in still younger ones one. may observe in the sap of the central vacuole a drop of concentration of the undetermined compounds which doubtlessly take part in the synthesis of compounds of high molecular value and of low osmotic activity (proteins). It results out of the data given in Fig. 4 that sugars are the main element present in the sap of the central vacuole during the growth and development of the ovules. The results concerning the changes of sugar concentration in the central vacuolar sap in developing ovules are in agreement with the results of studies on the osmotic value and with the author's hypothesis (1960a, c).

The results of our studies on the physical and chemical properties 
of the sap of the sentral vacuole (R y c z k ow ski 1960a, b, c, d, 1961) suggest the following conclusions:

1. Changes of the osmotic value, viscosity and specific gravity of the sap of the central vacuole, as well as changes of the concentration of sugars and undetermined substances present in it proceed with great dynamism.

2. Absolute values of the above mentioned properties differ greatly in various plant species. In some cases, even, they are different for individual plant specimens of the same species (Ryczkowski $1960 \mathrm{a}, \mathrm{c})$.

3. The elaboration of a universal, nutrient medium for cultures in vitro, both of the endosperm and probably of the embryo in their early stages of development seems most unlikely.

4. It is also probable that nutrient media of different composition and concentration will have to be used during the development of the endosperm and the embryo.

\section{SUMMARY}

1. A study was performed on the changes occuring in the concentration of sugars in the sap of the central vacuole during the development of the ovules of three species (Clivia sp., Haemanthus Katharinae, Haemanthus albiflos). The method of $\mathrm{S}$ a mog y i (1945 modified by Willis and Yemm (1955) was applied for the determinations of reducing and non reducing sugars. The accuracy of this method for dilutions of glucose and saccharose in the range of concentration from 12.5 to $100 \mu \mathrm{g}$ per mililiter was respectively \pm 1 and $\pm 2 \mu \mathrm{g}$.

2. It was established that the concentration of all soluble sugars, reducing and non reducing, present in the sap of the central vacuole, changes in a characteristic way (Fig. 2 and 3) during the development and growth of the ovule. The reducing sugars are transformed into non reducing sugars which in turn most probably change into starch.

3 . It was found that there is a dependence between the concentration of sugars in the central vacuolar sap, the amount of water in the ovule and its dry weight.

The author is deeply indebted to Professor F. Górski for his valuable critical advice in the elaboration of this work. 


\section{STRESZCZENIE}

1. W badaniach nad stężeniem cukrów w soku centralnej wakuoli zastosowano metodę Somogyi (1945), zmodyfikowaną przez Willisa i Yemma (1955). Dokładnośc metody dla roztworów glukozy i sacharozy w zakresie stężeń od 12,5 do $100 \mu \mathrm{g}$ wynosila \pm 1 , bądź też $\pm 1-2 \mu \mathrm{g}$.

2. Stwierdzono, że stężenie wszystkich cukrów rozpuszczonych w soku centralnej wakuoli, cukrów redukujących i cukrów nie redukujących zmienia się w trakcie wzrostu i rozwoju zalążków i że z cukrów redukujących odbywa się synteza cukrów nie redukujących, a z tych ostatnich najprawdopodobniej skrobia.

3. Ustalono, że istnieje pewien związek między stężeniem cukrów w soku centralnej wakuoli a ilością wody w zalążku oraz jego suchą masą.

Katedra Fizjologii Roślin UJ, Kraków, Grodzka 53

\section{REFERENCES}

B a jer A., 1955. Living smears from endosperm, Experientia (Basel) 11: 221.

B a jer A., 1957, Cine-micrographic studies on mitosis in endosperm. III., Exp. Cell Res. 13: 493-502.

Cutter jr. V. M. and Wils on K. S., 1954, Effect of cocnut endosperm and other growth stimulants upon the development in vitro of Cocos nucifera, Bot. Gaz. 115: 234-240.

Evans I. W., 1941, Changes in the biochemical composition of the corn kernel during development, Cereal Chem. 18: 468-473.

Grzesiuk S. and Rejow ski A., 1960, Study on Zea mays ssp. indurata grain physiology, Roczniki Nauk Roln. 81: 137-175.

K oblet R., 1940, Untersuchungen über die stoflichen Veränderungen in wachsenden und reifenden Weizenkorn, Ber. Schweiz. Bot. Ges. 50: 99-232.

Kolobkova E. V., 1958, Nitrogen metabolism in ripening seeds of Zea mays, Dokł. Akad. Nauk SSSR. 120: 907-908.

Pontovich V. E., Karimov Kh., 1960, Variation of amino acid content in the fruits of oil poppy, Fiziol. Rast. 7: 151-159.

Prokofiev A. A. and S o b o l y e v A. M., 1957, On the movement of phosphorus from leaves to seeds, Fiziol. Rast. 4: 14-23.

R y c zk ow ski M., 1960a, Observations on the osmotic value of the central vacuole sap in Haemanthus Katharinae Bak. ovule, Bull. Acad. Polon. Sci., Ser. sci. biol. 8: 143-148.

R y czkows ki M. $1960 \mathrm{~b}$, Investigations on viscosity and surface tension of central vacuole sap in the Haemanthus Katharinae Bak. ovule, Bull. Acad. Polon. Sci., Ser. sci. biol. 8: 149-154.

Ryczkowski M., 1960c, Changes of the osmotic value during the development of the ovule, Planta (Berl.). 55: 343-356.

Ryczkowski M., 1960d, Changes of the viscosity of central vacuolar sap during the development of the ovule. Planta (Berl.). 55: 357-364.

Ryczkowski M., 1961, Changes in the specific gravity of the central vacuolar sap in developing ovules. Bull. Acad. Polon. Sci., Ser. sci. biol., 9: 261-266. 
Samogy i M., 1945, A new reagent for the determination of sugars. J. Biol. Chem. 160: $61-68$.

S a n d ers M. E., B u r k h ol d e r P. R., 1948, Influence of amino acids on growth of Datura embryos in culture, Proc. Nat. Acad. Sci., 34: 516-526.

Straus J., 1960, Maize endosperm tissue grown in vitro III. Development of a syntetic medium, Amer. J. Bot., 47: 641-647.

Willis A. J. and Ye m m E. W., 1955, The micro-estimation of sugars in plant tissues, The New Phytologist, 54: 289-291.

Zhdanova L. P., L e b edyeva N. M., Chvizh V., 1960, Activity of the leaf apparatus and formation of seeds in sunflower plants, Fiziol. Rast., 7: 35-43.

Y em m E. W. and Willis A. J., 1954. Stomatal movements and changes of carbohydrate in leaves of Chrysanthemum maximum, The New Phytologist, 53: $373-396$. 